\title{
TEACHING ENGLISH USING CONTENT-BASED INSTRUCTION (CBI) IN IMPROVING STUDENTS' ENGLISH SPEAKING SKILL (A Classroom Action Research in the Second Grade Students of PoltekparLombok)
}

\author{
By \\ Lalu Mahsar \\ Sekolah Tinggi Pariwisata Mataram \\ Email: lombokmahsar2004@gmail.com
}

\begin{abstract}
This study examines the improvement of student speaking skill through content-based students' English speaking skill. More specificly, this study : (1) finding to what extent content-based instruction improved the students' speaking skill; and (2) to describe the teaching and learning situation when content-based instruction was applied in the speaking class. This study applied action research technique to conduct the research which is consisted of two cycles, with four meetings in each cycle; while each cycle consists planning, action, observation, and reflection. The research was conducted at Poltekpar Lombok Praya; the subjects of the research were the university students of second grade in the Academic year of 2018-2019. This study reveals that the teaching using CBI was effective in two aspects: (1) in improving students' speaking ability: students' speaking level increased; students could answer the teacher's questions; students could fluently communicate with their friends by using correct grammatical forms and appropriate vocabulary with good pronunciation; the use of mother tongue was reduced; (2) in improving class situation: the atmosphere in the whole class became alive; students enjoyed the speaking activities; there were many chances for students to practice their speaking skill; students had great motivation to learn speaking; speaking became easy and fun to the students. This study futher showed that CBI was effective and beneficial to improve the students' speaking competency and the classroom situation.
\end{abstract}

Keywords: Content-based Instruction \& Speaking Skill

\section{PENDAHULUAN}

Following the reform and opening-up policy, English entering a global modernized of economic society. It is being used in international business, politics, education, agriculture, science, technology. Inspte of that, English as an international language used by many people at all around the word and it plays a more and more important role in many parts of our life. Therefore, English has been made as the most popular foreign language learned by many students in the world.

In Indonesia, English is not only regarded as a second language, which is widely used in both formal and informal occasions, but also considered to be the initial foreign language that is being learned compulsorily since middle school till university level for many years (Actually, in recent years, the English course has been started since primary school). Therefore, English as a major course must be learned and mastered by every student.

Since the beginning of nineteen-nineties, the school program and curriculum policy of vocational school in Indonesia developed at very rapid speed. The objective of this school program and curriculum is to help the students be able to master the English in both literacy and communicative and the particular skills for their specific working fields. According to an investigation among all the students in the level of secondary school, nearly $60-70 \%$ students will take English program for tourism as their future career. However, the tourism program obligate using the English as a communication tool with visitors and people from different countries, while communication places great emphasis on the speaking capacity. People who 
can read, listen and write, but cannot speak will not be considered as a professional business man in the international business field.

Because of this, one of the goals of the Poltekpar Lombok is to improve the students' speaking skill and get them to be ready in their future job position, tourism guide, hotel industry, hotel management, etc. Thus, both the working skill and the speaking ability in the curriculum of the Poltekpar Lombok is main target and final goal of the students in the speaking class of Tourism English Department, therefore, is to have the oral communication capability. That is the students should be able to communicate with people on the daily tourism industry aspect accurately, fluently and appropriately.

According to Johnson (1998: 3), fluency refers to the absence of pauses and other indices of word-finding (or grammatical) difficulty. It is the natural language use or "the maximally effective operation of the language system so far acquired by the students" in situation where the learner's focus is on the effective communication of meaning. Accuracy means to the similarity to native speaker's grammar in the case of L2, or to prescriptive grammar in the case of L1. Accuracy embraces both formal correctness and appropriateness. It is deals with the production of structurally correct instances of L2. The concept of appropriateness is that language use is inevitably influenced by the context in which it is being used. All choices about aspects of language use, such as vocabulary and syntax, do not in really involved reference to the exact requirements of a fixed and unvarying 'standard English', so much as locate what is being written or said in terms of the varying degrees of formality that English language so uniquely allows, and within the richly varied register of the language (Jon and John, 2000: 107).

All in all, the students of the HRD Department should master the basic and specific speaking skill which is related to their daily life and future career. The students should have the capacity to blurt out the basic and specific English focus on the communication of meaning with the production of the structurally correct instances of L2 in terms of varying the degrees of formality that the English language allows.

However, there has a bitter case between the objective and the present situation in the speaking class of Tour Guide Department of Poltekpar Lombok). The speaking ability of the speaking class of TGD (Tour Guide Department Students) is still low, unsatisfying, and far from the expectations.

This can be seen especially in the class of HRD (Hotel Room Division). Mostly students in this class have low learning motivation and interest; they don't pay much attention to the class; they cannot answer the teacher's questions orally; they feel shy, nervous, and lack of confidence when asked by the teacher to answer questions or to conduct a presentation; in addition, they cannot fluently express their ideas by using appropriate vocabulary and correct grammatical forms; the students only can speak the first two or three sentences, and then totally get stuck and speak their mother tongue during the presentation; moreover, they often feel hesitate to pronounce the words, and most of them mispronounce the words. The students' low speaking ability must be dealing with the teaching and learning process. From the observation and interview with the teachers and students in the class of HRD, the causes of the problem can be mainly concluded as the follows:

Firstly, the text books chosen as teaching materials in the speaking class were long sentence-based stories without providing any communicative or meaningful activities to prompt the students' speaking ability. Meanwhile, the content in the text books was going far away from the practical English (in the students' opinion), which made the students feel it was useless or no meaning to attend the speaking class. Moreover, in the speaking class, the students were asked by the teacher to answer questions after reading the text loudly or silently, which made them feel very bored and thus reduce their interest in the speaking class.

Secondly, the speaking class was teacher- 
centered. It was the teacher who did most of her talk. The teacher often conveyed the content or knowledge of the text book to the students without letting the students make their own practice. Only these students whose mißids were wandering around were asked by the teacher to answer the questions passively. Yet it was not confidently and fluently answered.

Thirdly, the students were reluctant to speak in the speaking class. They often complained that they didn't know how to say it (something related to the topic) in English as they were lack of relevant vocabularies related to that topic. They were also afraid of being humiliated by their classmates or teacher as they couldn't produce correct pronunciation and speak the English fluently.

Fourthly, because of the environment condition and also because the English language has different grammar structures from Indonesian, it was not easy for the students to speak it as fluently as their native language. That's to say, it took a long time for the students to express or explain their ideas or thoughts. Thus, some short-tempered students spoke their native language in the speaking class, instead of the English.

According to the objective and the conditions mentioned above, it is very urgent and necessary for the teacher of speaking class to make every effort to change some of these situations into positive ones. In line with this, the researcher found the Content-Based Instruction (CBI) as an appropriate and effective approach that is especially suitable for the students in the HRD Department of Vocational \& Technique College. CBI is designed to provide second-language learners instruction in content and language. Content refers to the information or subject matter that we learn or communicate through language rather than the language used to convey it (Richard, 2006: 28). In other words, content is interpreted as the use of subject matter as a vehicle for second or foreign language teaching/learning.

\section{RESEARCH METHOD}

This chapter presents the method and process in conducting the study. They are (1) Setting of the research, (2) subject of the study, (3) procedures of the study, (4) technique data collections and (5) technique of data analysis. Setting of the Research

This research will be conducted at Poltekpar Lombok College, in Praya, NTB. This college is a state-run and full-time higher vocational college. There are two campuses with total together four Departements in this college, namely: Hotel Room Division (DK), Tour Guide Departement (UPW), Food Service $(\mathrm{TH})$ and Food Product (Kuliner), while the major of HRD belongs to the Room Division Departement. The numbers of students in this college are nearly 950 with different majors in different Departements.

This research is carried out in the campus of Poltekpar Lombok in Praya city from March 2019 to September 2019. Here is the detail research schedule:

Table 1. Of the Research Schedule

\begin{tabular}{|c|c|c|c|c|c|c|c|c|}
\hline \multirow[t]{2}{*}{ No. } & \multirow[t]{2}{*}{ Activity } & \multicolumn{7}{|c|}{ TIME: Year 2019} \\
\hline & & Mar & Apr & May. & Jun. & Aug. & Sep. & Nov. \\
\hline 1 & Pre-survey & $*$ & $*$ & & & & & \\
\hline 2 & Proposal & $*$ & $*$ & $*$ & & & & \\
\hline 3 & $\begin{array}{l}\text { Reviewing } \\
\text { literature }\end{array}$ & $*$ & $*$ & $*$ & & & & \\
\hline 4 & $\begin{array}{l}\text { Developing } \\
\text { Instrument }\end{array}$ & & $*$ & $*$ & $*$ & & & \\
\hline 5 & $\begin{array}{l}\text { Collecting } \\
\text { and } \\
\text { analyzing the } \\
\text { data }\end{array}$ & & & & * & $*$ & $*$ & \\
\hline 6 & $\begin{array}{l}\text { Writing the } \\
\text { report }\end{array}$ & & & & & $*$ & $*$ & $*$ \\
\hline 7 & $\begin{array}{l}\text { Collecting } \\
\text { the reports }\end{array}$ & & & & & & $*$ & $*$ \\
\hline
\end{tabular}

\section{Subject of the Research}

This research will be applied to the second grade students in Hotel Acomodation Class of English Department of Poltekpar in Academic year of 2018-2019. There are thirtyfive students in this class; ten female students, and twenty-five male students. The reason for choosing this class as the subject, it is because that the students' speaking ability in this class is still low and unsatisfying.

Based on the statements from the interview with both the teacher and students, the students generally had similar problems on 
the speaking class. According to the teacher, these students had lack of vigor, interest and motivation in the speaking class. They were always keeping silent in the class, and felt reluctant to speak. Moreover, they also couldn't answer the teacher's questions. Most of them were short of relevant vocabularies, and felt hesitate to pronounce the words. They couldn't fluently communicate with their classmates.

From the students' point of view, they stated that they felt very bored about the speaking class because they didn't want to read the novel again since they had read it in the dormitory already, and they wanted to learn something practical, something useful for their future career. Furthermore, they said that they couldn't express their thoughts or ideas with suitable expressions because of lack of vocabulary and because of the different grammar structure. Moreover, they said that they were not brave enough to speak English, they were afraid of making mistakes, so sometimes; they spoke Mother tongue, instead of English in the speaking class.

\section{Method of the Research}

In this study, the writer will apply the action research to conduct this study. According to Ebbutt (in Hopkins, 1985: 45 ), action research is about the systematic study of attempts to improve educational practice by groups of participants by means of their own practical actions and by means of their own reflection upon the effects of those actions.

Watts (1985: 118) also states that action research is a process in which participants examine their own educational practice systematically and carefully, using the techniques of research. It is based on the following assumptions:

1) Teachers and principals work best on problems they have identified for themselves

2) Teachers and principals become more effective when encouraged to examine and assess their own work and then consider ways of working differently.

3) Teachers and principals help each other by working collaboratively.
4) Working with colleagues helps teachers and principals in their professional development.

In the book of A Teacher's Guide to Classroom Research, Hopkins (1985: 44) notes that action research combines as substantive act with a research procedure; it is an action disciplined by enquiry, a personal attempt at understanding while engaged in process of improvement and reform. He also cited several definitions of action research from others in his book:

1) Rapoport (in Hopkins, 1985: 44) said that action research aims to contribute both to the practical concerns of people in an immediate problematic situation and to the goals of social science by joint collaboration within a mutually acceptable ethical framework.

2) Kemmis (inHopkins, 1985:44) writes: action research is a form of self reflective enquiry undertaken by participants in social (including educational) situations in order to improve the rationality and justice of (a) their own social or educational practices, (b) their understanding of these practices, and (c) the situations in which the practices are carried out.

3) Elliott (1991: 69) notes that Actionresearch might be defined as 'the study of a social situation with a view to improve the quality of action within it'. it aims to feed practical judgment of action situations, and the validity of the' theories' or hypotheses it generates depends not so much on 'scientific' tests of truth, as on their usefulness in helping people to act more intelligently and skillfully. In action-research 'theories' are not validated independently and then applied to practice. They are validated through practice. From all the definitions above, we know that action research is a worthwhile pursuit for educators for a number of reasons. Foremost among these is simply the desire to know more. Good teachers are, after all, themselves students, and often look for ways to 
expand upon their existing knowledge.

\section{Procedure of the Research}

According to Elliott (in Hopkins, 1993), the essentials of action research design are considered as per the following characteristic cycle:

1. Initially an exploratory stance is adopted, where an understanding of a problem is developed and plans are made for some forms of interventional strategy (The Reconnaissance \& General Plan).

2. Then the intervention is carried out (The Action in Action Research).

3. During and around the time of the intervention, pertinent observations are collected in various forms (Monitoring the implementation by Observation).

4. The new interventional strategies are carried out, and the cyclic process repeats, continuing until a sufficient understanding of (or implement able solution for) the problem is achieved (Reflection and Revision).

A representation of an AR protocol by Kemmis and McTaggart (1988) is provided in the following figure: writer will use the same steps in order to get the data objectively.

Figure 1: Cyclical AR model based on Kemmis and McTaggart (1988) in Burns (2013: 9)

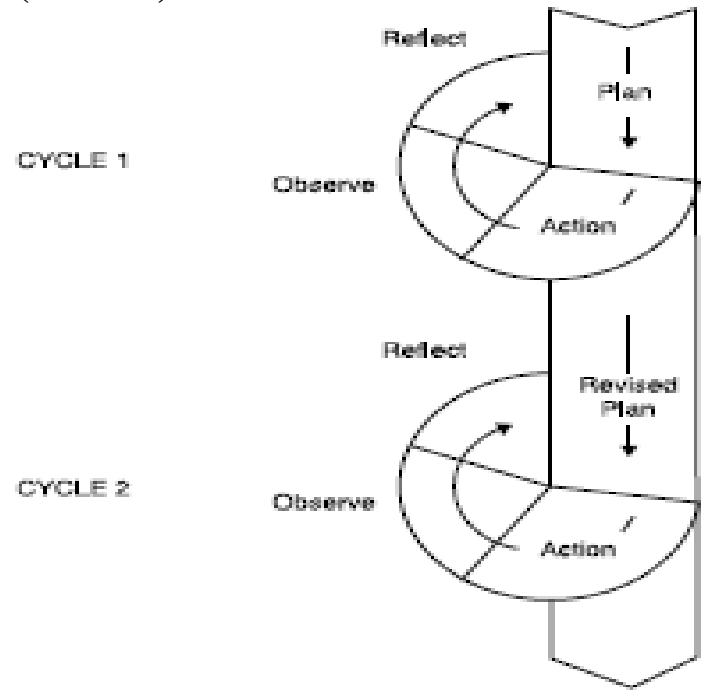

The study will be conducted to improve speaking skills of HRD students of Poltekpar Lombok using research procedures proposed by Kemmis and McTaggart; planning, action, observing and reflecting. There were two cycles that were carried out in the study. After the first cycle was conducted, the writer did reflection and revision to prepare the next cycle to make better improvement in teaching speaking. Those of stage are outlined below:

\section{Planning}

In this stage, the writer will plan: (a) the pretest in order to know the students' previous or original ability of their speaking; (b) the interview to both the teacher and students to know the previous teaching and learning process. That is to know what kinds of method, approach, techniques, and procedures that the teacher used during the teaching process and the students' opinion about the teacher's teaching strategies; (c) the specific lesson plan and teaching materials based on the problems identified; (d) the posttest to compare with the pretest in order to know if there is any improvement in the students' speaking by learning under the Content-base Instruction; and(e) the questionnaire after the implementation of the Content-based Instruction in order to get their opinion about the learning and teaching process.

\section{Acting}

In this step, the writer will carry out the entire detail action programs as planned above in the speaking class. The teaching activities or Content-based Instruction will be conducted step by step based on the lesson plans.

\section{Observing}

During the implementation of Contentbased Instruction, the students' learning process and their involvement or engagement, their responses, and their attitude of the learning progress in the speaking class will be observed and recorded by both of the writer and the collaborator through direct observation.

\section{Reflecting}

After carrying out the teaching and learning activities under the Content-based Instruction, the writer in this stage evaluates the result to see the effectiveness of the action program. By conducting the reflection, the writer will find whether it is necessary to conduct another cycle. 


\section{Techniques of Collecting the Data}

Ferrance (2000: 11) states that the collection of data is an important step in deciding what action needs to be taken. Multiple sources of data are used to better understand the scope of happenings in the class room or school. There are many vehicles for collection of data listed by Eileen as follows:

\begin{tabular}{|l|l|}
\hline interviews & $\begin{array}{l}\text { portfolios } \\
\text { field notes } \\
\text { photos } \\
\text { questionnaires } \\
\text { audiotapes } \\
\text { anecdotal } \\
\text { records } \\
\text { journals } \\
\text { focus } \\
\text { groups of meetings } \\
\text { cases studies }\end{array}$ \\
checklists & self-assessment \\
individual & \\
files & \\
videotapes & \\
surveys & \\
records - tests, \\
report cards, \\
attendance student \\
samples of stojects, \\
work, \\
performances
\end{tabular}

Adoptedfrom ferrace, (2011: 12)

In this research, the writer will collect the data from:

1. Interview

Interview is an activity conducted by asking questions face to face. During this research, the interview will be taken with both the teacher and students. By interviewing them, the writer will know the students speaking ability and their interest or motivation in the speaking class and the results of the teacher's teaching method or technique.

\section{Questionnaire}

Questionnaire is an investigation by asking some questions in the written form. In this research, the students will be asked to cross some statements in the questionnaire after the implementation of the Content-based Instruction in order to get their opinion about the learning and teaching process.

3. Observation

Observation is an activity of watching and recording action and behavior of the research participants in the class. In this research, the writer was helped by him collaborator to observe the teacher's teaching process and the students' learning activities and the learning progress in the speaking class. The data gained in the observation will be in the form of narrative text from the field note.

\section{REVIEW OF RELATED LITERATURE Speaking}

Speaking is an interactive process of constructing meaning that involves producing and receiving and processing information (Florez and Cunningham cite in Brown, 1994; Burns \& Joyce, 1997). Its form and meaning depend on the context in which it occurs, including the participants themselves, their collective experiences, the physical environment, and the purposes for speaking. It is often spontaneous, open-ended, and evolving. Rizvi (2006: 92) also states that speaking is an interactive communicative process that involves speakers and listeners. In communicative process, speakers need to learn to adapt their talk to the listeners; use a range of ways to express themselves; use talk to clarify their ideas and sustain their talk to develop thinking and reasoning.

Speaking is not the oral production of written language, but involves learners in the mastery of a wide range of sub-skills, which, added together, constitute an overall competence in the spoken language (McDonough and Shaw, 2003: 133). Bukart 1998 state that language learners need to recognize that speaking involves three areas of knowledge:

- Mechanics (pronunciation, grammar, and vocabulary):

- It is the ability to use the right words in the right order with the correct pronunciation.

- Functions (transaction and interaction): It is about the knowledge of knowing when clarity of message is essential (transaction/information exchange) and when precise understanding is not required (interaction/relationship building)

- Social and cultural rules and norms (turntaking, rate of speech, length of pauses between speakers, relative roles of 
participants): It refers to the understanding of how to take into account who is speaking to whom, in what circumstances, about what, and for what reasons.

In our lives, we use talk in different ways for different purpose and audiences. As a skill that enables us to produce utterances, when genuinely communicative, speaking is desire-and purpose-driven, in other words we genuinely want to communicate something to achieve a particular end. This may involve expressing ideas and opinions, expressing a wish or a desire to do something, negotiating and/or solving a particular problem, establishing and maintaining social relationships and friendships.

Burnett and Myes (2004: 24) put forward the following spoken language that may be used in many different ways.Speaking English can be particularly difficult because, unlike reading or writing, speaking happens in "real time," it requires the simultaneous use of a number of abilities which often develop at different rates. Generally, there are at least five components of speaking skill concerned with it such as following (Widiastuti cited from Syakur 1987: 3)

1) Comprehension: Oral communication certainly requires a subject to respond, to speech as well as to initiate it.

2) Grammar: It is needed for students to arrange a correct sentence in conversation. It is in line with explanation suggested by Heaton (1978: 5) that the student's ability to manipulate structure and to distinguish appropriate grammatical form in appropriate ones. The utility of grammar is also to learn the correct way to gain expertise in a language in oral and written form.

3) Vocabulary: One cannot effectively communicate or express their ideas both in oral and written form if they do not have sufficient vocabulary. So, vocabulary means the appropriate diction which is used in communication.

4) Pronunciation: Pronunciation is the way the students produce clearer language when they speak. It deals with the phonological process that refers to the component of a grammar made up of the elements and principles that determine how sounds vary and pattern in a language.

5) Fluency: Fluency can be defined as the ability to speak fluently and accurately. Fluency in speaking is the aim of many language learners. Signs of fluency include a reasonably fast speed of speaking and only a small number of pauses and "ums" or "ers". These signs indicate that the speaker does not have to spend a lot of time searching for the language items needed to express the message (Brown. 1997: 4).

Testing Speaking

A test is a procedure for measuring ability, knowledge or performance (Nagarja, 1996: 207). The speaking test is used to test students' speaking proficiency. When we give a speaking test to the students, normally, we want to know the followings:

- How accurately and appropriately the learner use the language (grammar and vocabulary)

- How well the learners develop the conversation and organize their ideas

- How fluently they speak

- How comprehensible their pronunciation is

- How positively they
contributed to the
conversation

According to Kitao and Kenji (1996: 2) a speaking test can be a source of beneficial backwash. If speaking is tested, it can encourage the teaching of speaking in classes. There are many techniques which can be used to test the speaking ability. Thorn bury (2005: 125-126) mentioned the most commonly used test types as follows:

\section{6) Interviews}

In conducting the interviews, students are called out one by one for their interview.

Interview is relatively easy to set up, but 
the rather formal nature of interview is hardly conducive to testing more informal, conversational speaking styles. It is also difficult to eliminate the effects of the interviewers questioning style.

\section{7) Live monologues}

The candidates prepare and present a short talk on a pre-selected topic. This eliminates the interviewer effect and provides evidence of the candidates' ability to handle an extended turn, which is not always possible in interviews. Other students can take the role as audiences; a question-and-answer stage can be involved. This can provide some evidence of the speaker's ability to speak interactively and spontaneously.

\section{8) Recorded monologues}

Recorded monologues are less stressful than a more public performance and, for informal testing; it is also more practicable in a way that live monologues are not.

Learners can take turns to record themselves talking about a favorite sport or pastime. The assessment of the recorded tests can be done after the event, and results can be 'triangulated'.

\section{9) Role-plays}

Students will be used to doing at least simple role plays in class, so the same format can be used for testing. The other 'role' can be played either by the tester or another student. The situation in the role-play should be better grounded in everyday reality. However, in the role-play test, the influence of the interlocutor is hard to control.

\section{0) Collaborative tasks and discussions}

These are similar to role-play except that the learners are not required to assume a role but simply to be themselves. In this performance, the learners' interactive skills can be observed in circumstances that close approximate real-life language use. Moreover, Kitao and Kenji (1996: 4) also suggest that testing speaking can use visual material.

Pictures, maps, diagrams, and other types of visual material can be used to test speaking without requiring the students to comprehend written or spoken material. Through careful selection of the material, the tester can control the vocabulary and, to some extent, the grammatical structures required. In the test of using visual materials, usually, the students are given a series of pictures which tell a story, and are required to put together a coherent narrative. A variation on this is to give the pictures in random order of the narrative to a group of students.

On a speaking test, getting the students to say something appropriate is only half the job. Scoring the test is equally challenging (Madsen, 1984: 166). However, Thom burry (2005: 127) suggests two main ways: either giving it a single score on the basis of an overall impression (called holistic scoring) or giving a separate score for different aspects of the task (analytic scoring). The holistic-scoring has the advantage of being quicker, and is probably adequate for informal testing of progress. It needs more than one scorer, and any significant differences in scoring should be discussed and a joint score negotiated.

Analytic-scoring takes longer, but compels testers to take a variety of factors into account and, if these factors are well chosen, is probably both fairer and more reliable. However, in the process of scoring, the scorer may be distracted by all the categories and lose sight of the overall picture. In describing the criteria levels of scoring, Hughes (2003: 110) said that the descriptions may be holistic or analytic and it was said that it is possible to use one method as a check on the other.

Madsen (1983: 167-168) state that the advantage of holistic grading is probably obvious. It concentrates on communication while not overlooking the components of speech. It is used to evaluate a various aspects simultaneously such as pronunciation, grammar, vocabulary, fluency, comprehension. According to Madsen (1983: 170), this rating scale can be adapted for the use of the teachers, and the teachers can prepare their own scale. Moreover, teachers with clearly identified evaluation criteria will want to rate their students on a holistic scale. Based on the theories above, the scoring rubric applied in this research is as follows: 
Table 2. Scoring Rubrics

\begin{tabular}{|c|c|c|}
\hline No.1 & Score & Indicator \\
\hline \multirow{3}{*}{ Fluency } & $\begin{array}{l}17-20 \\
13-16\end{array}$ & $\begin{array}{l}\text { Speech as fluently as that of a } \\
\text { native speaker } \\
\text { Speed of speech seems to be } \\
\text { slightly affected by language } \\
\text { problems }\end{array}$ \\
\hline & $9-12$ & $\begin{array}{l}\text { Speech and fluency are } \\
\text { strongly affected by language } \\
\text { problems }\end{array}$ \\
\hline & $5-8$ & $\begin{array}{l}\text { Often hesitant and forced } \\
\text { silence by language } \\
\text { limitation 1-4 Speech is so } \\
\text { halting and fragmentally } \\
\text { that makes communication } \\
\text { impossible }\end{array}$ \\
\hline No. 2 & $17-20$ & $\begin{array}{l}\text { Almost no inadequacy or } \\
\text { inaccuracy }\end{array}$ \\
\hline \multirow{4}{*}{ Vocabulary } & $\begin{array}{l}13- \\
16\end{array}$ & $\begin{array}{l}\text { Few times inadequate or } \\
\text { inaccurate }\end{array}$ \\
\hline & $9-12$ & $\begin{array}{l}\text { Sometimes inadequate or } \\
\text { inaccurate }\end{array}$ \\
\hline & $5-8$ & $\begin{array}{l}\text { Inaccurate or in adequate } \\
\text { that affect the } \\
\text { understanding }\end{array}$ \\
\hline & $1-4$ & $\begin{array}{ll}\begin{array}{l}\text { Inadequate } \\
\text { communication }\end{array} & \text { for } \\
\end{array}$ \\
\hline No. 3 & $\begin{array}{l}17- \\
20\end{array}$ & $\begin{array}{ll}\text { No } & \text { grammatical } \\
\text { inaccuracy } & \end{array}$ \\
\hline \multirow{6}{*}{ Grammar } & $\begin{array}{l}13- \\
16\end{array}$ & $\begin{array}{ll}\text { Few } & \text { grammatical } \\
\text { inaccuracy }\end{array}$ \\
\hline & $9-12$ & $\begin{array}{l}\text { Grammatical inaccuracy } \\
\text { does not impede the } \\
\text { understanding }\end{array}$ \\
\hline & $5-8$ & $\begin{array}{l}\text { Grammatical inaccuracy } \\
\text { does not seriously impede } \\
\text { understanding }\end{array}$ \\
\hline & $1-4$ & $\begin{array}{l}\text { Grammatical inaccuracy } \\
\text { makes understanding } \\
\text { almost impossible }\end{array}$ \\
\hline & $\begin{array}{l}17- \\
20\end{array}$ & Accurate pronunciation \\
\hline & $\begin{array}{l}13- \\
16\end{array}$ & $\begin{array}{ll}\begin{array}{l}\text { Few } \\
\text { pronunciation }\end{array} & \text { inaccurate } \\
\end{array}$ \\
\hline \multirow{3}{*}{ Pronunciation } & $9-12$ & $\begin{array}{l}\text { Inaccuracy of pronunciation } \\
\text { does not impede } \\
\text { understanding }\end{array}$ \\
\hline & $5-8$ & $\begin{array}{lr}\text { Inaccuracy } & \text { of } \\
\text { pronunciation } & \text { does } \\
\text { seriously } & \text { impede } \\
\text { understanding } & \\
\end{array}$ \\
\hline & $1-4$ & $\begin{array}{lr}\text { Inaccuracy } & \text { of } \\
\text { pronunciation } & \text { makes } \\
\text { understanding } & \text { almost } \\
\text { impossible } & \\
\end{array}$ \\
\hline No. 5 & $\begin{array}{l}17- \\
20\end{array}$ & $\begin{array}{l}\text { Understands everything in } \\
\text { normal } \\
\text { conversation }\end{array}$ \\
\hline \multirow[t]{2}{*}{ Comprehension } & $\begin{array}{l}13- \\
16\end{array}$ & $\begin{array}{l}\text { Understands quite well the } \\
\text { normal educated speech/ } \\
\text { dialogue, but sometimes } \\
\text { need repetition or } \\
\text { rephrasing }\end{array}$ \\
\hline & $9-12$ & $\begin{array}{l}\text { Understands simplified } \\
\text { speech/dialogue but need } \\
\text { repetition and rephrasing }\end{array}$ \\
\hline
\end{tabular}

\begin{tabular}{|l|l|}
\hline \multirow{2}{*}{$5-8$} & $\begin{array}{l}\text { Understands only slow, } \\
\text { very simple speech, require } \\
\text { repetition and rephrasing }\end{array}$ \\
\hline $1-$ & $\begin{array}{l}\text { Understands too little for } \\
\text { the simplest type } \\
\text { conversation }\end{array}$ \\
\hline
\end{tabular}

The Nature of Content-Based Instruction

Content-Based Instruction (CBI) is a significant approach in second language acquisition Brinton, Snow, \& Wesche, (1989). Furthermore, Richard and Roger (2001: 204) says that, CBI refers to an approach to second language teaching in which teaching is organized around the content or information that students will acquire, rather than around a linguistic or other type of syllabus. Furthermore, Krahnke (1987: 65) defines CBI as the teaching of content or information in the language being learned with little or no direct or explicit effort to teaching the language itself separately from the content being taught. Moreover, Brinton, Snow, and Wesche (1989: 2) offered the definition of $\mathrm{CBI}$ as "the integration of particular content with languageteaching aims". The activities in CBI class are centered on the content being taught and students are expected to learn the content by using the target language. Stewart (2008: 12) states that the proponents of content-based instruction argue that language is most effectively learned in the context of relevant and meaningful content.

According to Richard (2006: 28), content refers to the information or subject matter that we learn or communicate through language rather than the language used to convey it. In addition, Da Silva in Hale (2008: 3) identifies content as a crucial part of language learning and the separation of language from content as both arbitrary and artificial. Historically, the word content has changed its meaning in language teaching. Content used to refer to the methods of grammar-translation, audio-lingual methodology and vocabulary or sound patterns in dialog form. Recently, content is interpreted as the use of subject matter as a vehicle for second or foreign language teaching/learning

$\mathrm{CBI}$ is developed under the framework of communicative language teaching (CLT), it is grounded on the following two central 
principles (Richard and Roger, 2001: 207):

a. People learn a second language more successfully when they use the language as a means of acquiring information, rather than as an end in it.

b. CBI better reflects learners' needs for learning a second language.

Vyas and Patel (2009: 120) state that CBI is important to produce students who comprehend English without translating into their native language, choosing meaningful content is essential. Through communicationbased instruction focused on content, students are able to pick up not only the communicative skills that are necessary for effective language, but also learning new subject matter.

Based on the definitions and descriptions above, it can be concluded that CBI is an approach to second language teaching in which teaching is organized around the content or information, and students learn the second language with little or no direct or explicate effort as the content or information is interpreted as the use of meaningful authentic materials (including text, pictures, newspapers, etc.,) as the vehicle to motivate the students to get involved in the language teaching and learning process.

\section{The Advantages of Content-based Instruction}

CBI is believed to have many advantages.

These advantages are listed as follows;

a) It can make learning a language more interesting and motivating. Students can use the language to fulfill a real purpose, which can make students both more independent and confident.

b) Students can also develop a much wider knowledge of the world through CBI which can feed back into improving and supporting their general educational needs.

c) $\mathrm{CBI}$ is very popular among EAP (English for Academic Purposes) teachers as it helps students to develop valuable study skills such as note taking, summarizing and extracting key information from texts.

d) Taking information from different sources, re-evaluating and restructuring that information can help students to develop very valuable thinking skills that can then be transferred to other subjects.

e) The inclusion of a group work element within the framework given above can also help students to develop their collaborative skills, which can have great social value.

Moreover, Chamot and O'Malley (1994: 26) said that there are at least four reasons for incorporating content into the English as a Second Language (ESL) class as follows:

a. Content provides students with an opportunity to develop important knowledge in different subject areas.

b. Students are able to practice the language functions and skills needed to understand, discuss, read about, and write about the concepts developed.

c. Students exhibit greater motivation when they are learning content than when they are learning language only.

d. Content provides a context for teaching students learning strategies

\section{Discussion}

The research which is applying action research to optimize Content-based Instruction in improving students' speaking ability brought satisfying results both in terms of the improvement of the students' speaking ability and the classroom situation. The findings then can be theorized into two major points as follows: (1) CBI can improve students' speaking ability; and (2) CBI can improve the classroom situation.

Content-Based Instruction can improve students' speaking ability

Based on the observation in both Cycle 1 and Cycle 2, it was found that each indicator of speaking was improved. There were improvements on: (a) students' pronunciation, most of the students could say something in a good stress and intonation, they could pronounce the words well; (b) Students' vocabulary, students learned many useful and 
practical vocabularies related to each topic in the class; most of the students could apply the words correctly in conducting different activities or games; (c) students' grammar. Most of the students could arrange and use the proper words order, could change the verb forms into their different tense according to different situation. It was beneficial for students to learn and practice the grammar with the each other in the communicative discourse. As cited by Hale from Ellis' work (2008: 27) that grammar should be integrated with communication if enhancing communicative competence is the goal of the second language teaching. Moreover, Murcia (2002) claims that the function of any form or structure should be understood at the discourse level within the context; (d) students' comprehension, most of the students could answer the teacher's and their friends' questions, and could work with their classmates in the communicative activities, and (e) Fluency, as the students had been taught many topic related words and expressions, and also had practiced the pronunciation in different activities in the pretask phase. Most of students could fluently conduct or complete their tasks assigned by the teacher in the task phase. They always got some experience from the previous students who performed at the beginning.

By proving the useful and practical content, and applying the interesting activities or games to the students, the students' speaking ability was significantly improved as each of the speaking indicator showed in the previous part. As the content or topics fell under the students' interest, the students had great motivation to learn the language.

Providing the practical and useful content and interesting activities means providing opportunities for effective interaction. Robinson and Ellis (2008) state that effective interaction gives students multiple opportunities for the goal-directed negotiation of meaning. This is required for effective support of integrated content and language learning for two reasons. First, as they interact and create meaning, students map new content knowledge onto prior content knowledge. They do this through spoken discourse. Second, students notice the language used, they retrieve needed language from memory, and they generate new configurations of language through spoken discourse with each other and with their teacher.

Moreover, CBI can apply different interesting activities to help the students to learn and practice their speaking skill. According to Grandall and Shaw (1992 and 1997)

The arrangements in the activities allow students to share responsibility and work together to complete tasks. Small group work, team learning, jigsaw reading, and peer editing are among the many techniques CBI calls on, to provide students with ample opportunities to interact, share ideas, test hypotheses, and construct knowledge together in a low-risk forum.

\section{CBI can improve the classroom situation.}

It was found that the students' learning motivation was increased and the whole classroom situation was changed after the implementation of CBI; the speaking class was not silent anymore. It was full of activities and games, and the students enjoyed the activities and games very much. The class became students-centered; it was the students who did most of the talks. In Hale's work (2008: 28), Parameter sees CBI as contributing to affective aspects, such as enjoyment, increased motivation and decreased anxiety about making mistakes, in addition to introducing intellectual, social and cultural aspects.

Vyas and Patel (2009: 131) said that Varying the choice of topics and themes is essential in order to engage students in learning the content through English; appealing topics and themes encourage them actively participate in class.

Active participation in class enhances students' relationships with one another, creating a positive influence on classroom atmosphere.

Grabe and Stoller also said that Keeping students motivated and interested are two important factors underlying Content-based 
Instruction. Motivation and interest are crucial in supporting student success with challenging, informative activities that support success and which help the student learn complex skills.

Besides, Krapp, Hidi, and Renninger (1992) state that situational interest triggered by environmental factors, may evoke or contribute to the development of long-lasting individual interests. Because CBI is student centered, one of its goals is to keep students interested and motivated by generating stimulating content instruction and materials. Little wood (1981)

Because CBI falls under the more general rubric of communicative language teaching (CLT), the CBI classroom is learner rather than teacher centered. In such classrooms, students learn through doing and are actively engaged in the learning process. They do not depend on the teacher to direct all learning or to be the source of all information. Central to $\mathrm{CBI}$ is the belief that learning occurs not only through exposure to the teacher's input, but also through peer input and interactions. Accordingly, students assume active, social roles in the classroom that involve interactive learning, negotiation, information gathering and the co-construction of meaning (Lee and Van Patten, 1995).

Based on the above discussion, it can be noticed that CBI is an effective approach to improve students speaking skill.

\section{CONCLUSIONS AND SUGGESTIONS}

This chapter is devoted to conclude the results of the study. The results of the study could answer the formulated problems as stated previously. This research was done in two cycles, and the results were obtained from the pre-research observation and interview, the pre-test, the post-test of Cycle 1 and Cycle 2, the post-research questionnaire and the interview to the students after the implementation of the CBI. This chapter consisted of two parts: conclusion, implications, and suggestions. The detailed presentation of this chapter was as follows:

\subsection{Conclusions}

This research was conducted to solve the problems faced by the students of class Hotel Room Division of Poltekpar in improving their speaking skill. After analyzing the data gained from the pre-test, the writer found that the students speaking ability was low and unsatisfying. The mean score of the pre-test was 59.6, and seventeen or forty-five percent students were under the average level.

CBI had more strengths than weaknesses. CBI increased students' participation in the speaking class by the practical and interesting content. CBI is very flexible, it could accommodate various types of activities which were motivating the students to participate in the speaking task, and it could adjust the students work in individual, in pair and in groups according to the content. Pair and group works were found to eliminate students' psychological barriers and increase students' self-confidence. Moreover, in the class, students were not only learning from their Teacher but also from their friends. In the group work, each member of the group worked very hard to complete their group work and didn't want to lag behind. They helped their group members and competed with other group members.

\section{Suggestions}

This research indicates that the implementation of CBI in teaching speaking showed many positive effects in the students' progress. Based on the result of the study, there are some suggestions put forward to the English teachers, the students, and other writers.

\section{a. Teacher}

The teacher should try to select the content or different topics based on the school's requirements and also should meet the students' needs. Practical and interesting content can motivate students to actively engage in the speaking activities. Besides, the teacher should pay attention to that the content or topics given to the students should not be very difficult; otherwise, the students may lose interest and get frustrated in the speaking activity.

\section{b. Students}

The students of HRD Department of 
Poltekpar should change their attitude towards learning speaking skill. They should be more confident and braver to speak English rather than be afraid of making mistakes or be humiliated by their friends. They should know that mistakes are parts of learning process. Without making mistakes we cannot find our progress. Students should practice English every day in the daily life. As practice makes perfect, by practicing every day, their speaking skill will be improved day by day.

\section{c. Writers}

CBI is one of interesting and joyful approach that can be applied in the classroom to improve the students' speaking skill. Although the writer has tried to do the best in implementing the CBI approach to improve the students' speaking skill, the result of this study is not very perfect; therefore, the writer hopes that the other writers could help to eliminate the weaknesses which were found in this study.

\section{BIBLIOGRAPHY}

[1] Annabelle, Hernández Herrero (2005). Content-based instruction in an English oral communication course at the university of costa rica http://revista.inie.ucr.ac.cr/articulos/22005/archivos/oral.pdf on August 2, 2010

[2] Ayari, Salah (__ ). Content-based Instruction and its Application to the Arabic Language Classroom. Texas A\&M University. Accessible at: http://www.isna.net/Documents/Programs/ Content-based_instruc\%20tion\%5B1\% 5D..Ayari.pdf on July 28, 2010

Accessible at: http://www.google.com/books

[3] Baker, Joanna and Wstrup, Heather (2003). Essential speaking skills: a handbook for English language teachers. Published by Continuum.

[4] Bygate, Martin (1987). Speaking. Oxford: Oxford University Press

[5] Burkart, Grace Stovall (1998). Modules for Professional preparation of teaching assistant in Foreign Languages, Spoken Language: What it is and how to teach it.
Washington, DC: Center for Applied Linguistics. Accessible at: http://www.nclrc.org/essentials/speaking/s pindex.htm

[6] Cotter, Hue (__ ). ESL Speaking for Advanced Students. Accessible at: http://hubpages.com/hub/esl-speakingadvanced

[7] Cathy, Burnett and Julia, Myers (2004). Teaching English 3-11: the essential guide Continuum.

[8] Dorothy, Gabel (1995). An Introduction to Action Research. Accessible at: http://physicsed.buffalostate.edu/danowne r/actionrsch.html

[9] Davison, Jon and Moss John (2000). Issues in English teaching. Published by Routledge USA and Canada

[10]Flohr, Susanne and Paesler, Pia (2006). Teaching Listening and Speaking. Drude und Bindung: Books on Demand Gmblt, Norderstedt Germany.

[11] Hale, Chris (2008) Charting New Courses: Second Language Action Research in Japanese Junior and Senior High School. Accent Asia Press.

[12]Hopkins, David (1985), A Teacher's Guide to Classroom Research, Buckingham.

Philadelphia: Open University Press

[13]Huebner, Theodore (1960). Audio Visual Technique in Teaching Foreign Language, New York: Cambridge University Press

[14]Keith Johnson, Helen Johnson (1998), Encyclopedia dictionary of applied linguistics: a handbook for language teaching. Blackwell Publishing Ctd.

[15]Lyster, Roy (2007). Learning and teaching languages through content: a counterbalanced approach. John Benjamins B.V.

[16] Madsen, Harold S (1984), Techniques in testing. Oxford: Oxford University Press

[17] Nunan, David (1989). Designing Tasks for the Communicative Classroom. Cambridge: Cambridge University Press.

[18]Florez, MaryAnn Cunningham (1999). Improving Adult English Language Learners' Speaking Skills. Source: National Clearinghouse for ESL Literacy 
Education Washington DC. Accesible at: http://www.ericdigests.org/2000-

3/adult.htm

[19]Huifang, Shang (2006). Content-based Instruction in the EFL Literature Curriculum. The Internet TESL Journal, Vol. XII, No. 11, November 2006. Accessible at: http://iteslj.org/Techniques/Shang-

CBI.html

[20] Kayi, Hayriye (2006). Teaching Speaking: Activities to Promote Speaking in a Second Language. Source: The Internet TESL Journal, Vol. XII, No. 11. Accessible at: http://iteslj.org/Techniques/Kayi-

TeachingSpeaking.html

[21] Kathleen M. Bailey (__ ) . Issues in Teaching Speaking Skills to Adult ESOL Learners. Accessible at: http://www.ncsall.net/?id=859

[22]Kitaom S. Kathleen and Kenji Kitao (1996). Testing Speaking. Document Resume ERIC

[23]Peachey, Nik (2003). Content-based instruction. British Council BBC. http://www.teachingenglish.org.uk/think/a rticles/content-based-instruction Accessed on July 21, 2010

[24]Robinson \& Ellis, (2008). Integrated Content and Language Instruction, Accessible at http://www.cal.org/resources/digest/integr atedcontent.html

[25]Richards, Jack C and Rodgers, Theodore Stephen (2001). Approaches and methods in language teaching. Cambridge: Cambridge University Press.

[26]Richards, Jack C (2006). Communicative Language Teaching Today. Cambridge: Cambridge University Press.

[27]Rizvi, M Ashraf (2005). Effective

Technical Communication. Published by the Tata McGraw-Hill Publishing Company Limited.

[28] Stryker, Stephen B and Leaver, Betty Lou (1997). Content-based instruction in foreign language education: models and methods. Washington D. C: Georgetown University Press.
[29]Ur, Penny (1996). A course in language teaching: practice and theory. Cambridge: Cambridge University Press.

[30] Vyas, Manish A and Pate, Yogesh L. (2009) Teaching English as a second language: A new pedagogy for a new century. Asoke K. Ghosh, PHI Learning Private Limilted, New Delhi

[31]Widiastuti, Rini ( 2009). Teaching Speaking Through Dialogue.

http://etd.eprints.ums.ac.id/332/

Accessed on February 12, 2010

[32] William Grabe, Fredricka L. Stoller (_ _ ). Content-based instruction: research Foundations. Accessible at: http://www.univie.ac.at/Anglistik/Dalton/S E08\%20cli1/Stoller\&Grabe970001.pdf on July 21, 2010

[33] Widiastuti Rini (2008) Teaching Speaking through Dialogue http://etd.eprints.ums.ac.id/332/

[34] Ya-Ling Tsai (2010). The Impact of Content-Based Language Instruction on EFL Students' Reading Performance. Accessible at: http://www.ccsenet.org/journal/index.php/ ass/article/viewFile/5379/4492 